\title{
KEBIJAKAN FORMULATIF SATUAN POLISI PAMONG PRAJA (SATPOL PP) DI KABUPATEN TABANAN (Studi Kasus Penertiban Gepeng dan Pedagang Kaki Lima dalam Perwujudan Tata Kota)
}

\author{
Ratna Artha Windari ${ }^{1}$, Ni Ketut Sari Adnyani ${ }^{2}$ \\ 1,2 Jurusan IImu Hukum, Universitas Pendidikan Ganesha \\ Singaraja, Indonesia
}

Email: ratna_windari@yahoo.co.id, sariadnyani@yahoo.com

\begin{abstract}
Abstrak
Penelitian ini bertujuan untuk: 1) mengkaji model formulatif kebijakan SATPOL PP Tabanan terhadap penertiban Gepeng dan Pedagang Kaki Lima dalam perwujudan tata kota sebagai research modle bagi SATPOL PP di daerah Kabupaten/Kota lain di Provinsi Bali, dan 2) menganalisis dan memformulasikan implikasi keberhasilan teknis rancangan tata kota yang dapat diadopsi melalui model formulatif kebijakan SATPOL PP Tabanan dalam penataan ruang wilayah perkotaan ditinjau dari Perda RTRWP Bali No.16 Tahun 2009. Jenis penelitian yuridis normatif dengan pendekatan field research (penelitian lapangan), sampel/responden secara proporsional yang difokuskan pada organisasi perangkat daerah, teknik analisis data secara deskriptif kualitatif. Hasil penelitian menunjukkan: 1) model kebijakan formulatif keberhasilan SATPOL PP Tabanan di dalam penertiban Gepeng dan Pedagang kaki lima adalah melalui tahap pengumpulan opini, tahap pendekatan dan komunikasi, tahap public hearing, sosialisasi dan negosiasi, tahap kesepakatan, tahap eksekusi terhadap pelanggaran, yang diikuti dengan pembinaan melalui lembaga sosial seperti balai latihan kerja (BLK). 2) implikasi keberhasilan model kebijakan formulatif terhadap penertiban gepeng dan pedagang kaki lima melalui Satpol PP Tabanan berupa tata kota yang bersih dan teratur, hasil jual, penyediaan tempat permanen berupa los-los resmi, penyediaan jasa pelayanan parkir, termasuk pengembangan jenis usaha kreatif hasil kerajinan tangan warga binaan.
\end{abstract}

Kata Kunci: Kebijakan Formulatif, Satpol PP, Gepeng dan Pedagang kaki lima

\begin{abstract}
This research aims to: 1) assess the model formulatif SATPOL policy towards policing Gepeng Tabanan PP and Street Vendors in the embodiment of urban design as a research SATPOL models for PP in the District / other cities in the province of Bali, and 2) analyze and formulate implications success technical design urban planning models that can be adopted by policy formulatif SATPOL PP Tabanan in urban spatial planning in terms of Regulation 16 of 2009 RTRWP Bali. Kind of normative juridical approach field research (field research), sample / respondents proportionately focused on regional organizations, descriptive
\end{abstract}


qualitative data analysis techniques. The results of a research study is a sample intended formulatif policy model that can be studied from Tabanan PP SATPOL success in carrying out its role, the implementation of the duties SATPOL PP Tabanan can be used as research samples by SATPOL PP in the Regency / City else in Bali. Results show that: 1) formulatif policy models in policing Gepeng and sidewalker trader are gathering opinions from community, communication, public hearing, negosiation, guidance and control wich is doing by vocational training centers (BLK). 2) implications of formulatif policy are city planning clean and orderly, providing a place to trade, parking services, and the development of creative business.

Keywords: Formulatif Policy, Satpol PP, Gepeng and Sidewalk Trader

\section{PENDAHULUAN}

Berdasarkan ketentuan Pasal 1

ayat (5) Undang-undang Nomor 32 Tahun 2004, Otonomi daerah adalah hak, dan kewajiban daerah otonom untuk mengatur dan mengurus sendiri urusan pemerintah dan kepentingan masyarakat setempat sesuai dengan peraturan perundang-undangan. Pengertian ini memberikan implikasi bahwa Pemerintah Pusat memberikan kewenangan seluas-luasnya kepada daerah untuk mengatur rumah tangganya sendiri. Daerah dengan inisiatifnya sendiri dapat menyelenggarakan Pemerintahan Daerah dengan membuat peraturanperaturan daerah.

Penyelenggaraan otonomi daerah akan berjalan lancar apabila komponen-komponen yang sudah diprogramkan dalam Perda dilaksanakan dengan baik, dan juga ditunjang oleh kondusifnya situasi dan kondisi suatu daerah dilihat dari sisi ketentraman dan ketertiban umum yang dapat menunjang terealisasinya sektorsektor produktif daerah dalam menunjang pembangunan daerah yang bersangkutan. Ketentraman dan ketertiban umum yang dimaksudkan adalah suatu keadaan dinamis yang memungkinkan Pemerintah, Pemerintah Daerah dan masyarakat dapat melakukan kegiatannya dengan tentram, tertib, dan teratur. Untuk mendukung terselenggaranya program daerah, baik di lingkup daerah Provinsi maupun daerah Kabupaten/Kota menempatkan Satuan Polisi Pamong Praja dengan konsekwensi tugas yang dijamin secara yuridis.

Dalam rangka mendukung terselenggaranya program daerah, baik di lingkup daerah Provinsi maupun daerah Kabupaten/Kota menempatkan Satuan Polisi Pamong Praja dengan konsekwensi tugas yang dijamin secara yuridis. Diberikannya kewenangan pada Satpol PP untuk memelihara keamanan dan ketertiban masyarakat bukanlah tanpa alasan. Namun, didukung oleh dasar pijakan yuridis yang jelas, sebagaimana dinyatakan dalam Undang-Undang Nomor 32 Tahun 2004 tentang Pemerintahan Daerah, khususnya Pasal 13 dan Pasal 14 pada huruf $c$, yang menyebutkan: urusan wajib yang menjadi kewenangan Pemerintah Daerah meliputi penyelenggaraan ketertiban umum dan ketentraman masyarakat. Demikian pula dalam Pasal 148 dan Pasal 149 Undang-Undang Nomor 32 Tahun 2004 
tentang Pemerintahan Daerah yang mengamanatkan dibentuknya Satuan Polisi Pamong Prajauntuk membantu Kepala Daerah dalam menegakkan Peraturan Daerah dan penyelenggaraan ketertiban umum serta katentraman masyarakat.

Guna mewujudkan tata ruang wilayah perkotaan yang teratur dan tertib berdasarkan ketentuan umum PP No. 32 Tahun 2004 tentang Satuan Polisi Pamong Praja, Satuan Polisi Pamong Praja adalah sebagai salah satu perangkat pemerintah daerah dalam memelihara dan menyelenggarakan ketentraman dan ketertiban umum serta menegakkan Peraturan Daerah.

Dalam usulan penelitian yang dirancang ingin menjadikan model pelaksanaan tupoksi SATPOL PP di Kabupaten Tabanan sebagai salah satu Research Modle terhadap upaya penenertiban gepeng dan pedagang kaki lima yang dianggap masih meresahkan daerah Kabupaten/Kota lain di provinsi Bali yang dikategorikan belum berhasil melakukan penanganan terhadap kedua aspek tersebut.

Melihat kedudukan dan fungsinya dalam penataan wilayah khususnya terkait dengan tata kota dalam pelaksanaan fungsinya SATPOL PP Tabanan menurut field research yang telah dilaksanakan dikategorikan berhasil menjalankan tupoksinya karena sering berhasil ketika terjun langsung ke lapangan untuk melakukan tindakan penertiban terhadap warga masyarakat yang dinilai tidak mengindahkan prosedur pembangunan tata kota yang baik.

Tindakan penertiban yang dilakukan oleh SATPOL PP adalah berupa razia terhadap gepeng (pengemis jalanan) yang meresahkan warga masyarakat sekitar karena tak jarang aksi memintamintanya tersebut dilaksanakan dengan cara pemaksaan. Demikian juga halnya dengan pedagang kaki lima yang sering memadati badan jalan dan mengganggu arus lalu lintas. Permasalahan seperti ini menjadi sorotan utama bagi pemerintah daerah untuk menerjunkan perangkat daerah terkait seperti SATPOL PP untuk melakukan tindakan preventif maupun represif dengan penanganan langsung ke lapangan berhadapan dengan para gepeng dan pedagang kaki lima yang senantiasa melakukan perlawanan ketika aparat SATPOL PP melakukan tindakan penjaringan/razia.

Keberhasilan dari pelaksanaan tupoksi tersebut SATPOL PP Tabanan dapat dijadikan research sample oleh SATPOL PP di daerah Kabupaten/Kota lain di propvinsi Bali yang cenderung mengalami kesulitan dalam melakukan penertiban karena umumnya di daerah lain selain di Tabanan pada saat penanganan ke lapangan sering dijumpai bentrok fisik antara SATPOL PP dengan para pihak yang akan dijaring untuk dilakukan tindakan penertiban. Penjaringan gepeng dilakukan karena sudah berkali-kali pihak SATPOL PP meringkus dan mengembalikan gepeng tersebut ke daerah asal akan tetapi tetap kembali lagi ke kota tersebut dengan dalih mencari nafkah. Penertiban terhadap pedagang kaki lima oleh SATPOL PP, sebelum razia dan penggusuran dilakukan berbagai macam layangan peringatan melalui surat dan himbauan secara bertahap telah ditempuh yang berisi anjuran untuk segera mengosongkan area berjualan di badan 
jalan tetapi hal tersebut tidak diindahkan oleh pedagang kaki lima.

\section{METODE}

Jenis penelitian adalah yuridis normatif dengan pendekatan dalam penelitian yaitu penelitian lapangan, pendekatan tersebut karena untuk menganalisis dan memformulasikan positive image yang dapat diadopsi melalui model formulatif kebijakan SATPOL PP Tabanan dalam penataan ruang wilayah perkotaan. Pemilihan responden secara proporsional yang difokuskan pada masyarakat, organisasi perangkat daerah, yaitu SATPOL PP Kabupaten Tabanan, satuan kerja pemerintah daerah (SKPD) di propinsi dan kabupaten/kota dengan responden para pejabat pemerintah daerah yang diperkirakan memahami dan dapat memberikan informasi yang relevan. Lokasi penelitian di Kabupaten Tabanan. Pemilihan dan penentuan lokasi dan subjek penelitian ini dilakukan secara purposive (bertujuan) sesuai dengan fokus masalah dan kebutuhan data penelitian. Berdasarkan rumusan permasalahan yang telah dikemukakan, maka ruang lingkup penelitian difokuskan pada model kebijakan formulatif SATPOL PP di Kabupaten Tabanan (Studi Kasus Penertiban Gepeng dan Pedagang Kaki Lima dalam Perwujudan Tata Kota). Instrumen dalam penelitian ini, menggunakan prinsip bahwa peneliti adalah instrumen utama penelitian (human instrument). Untuk dapat memperoleh hasil penelitian yang diharapkan sesuai dengan tujuan penelitian, maka teknik analisis data yang digunakan adalah deskriptif kualitiatif dalam bentuk kategorisasi dan kodifikasi data,
Reduksi data, Penyajian dan klasifikasi data, Penarikan kesimpulan dan verifikasi data.

\section{HASIL DAN PEMBAHASAN}

\section{Model Formulasi Kebijakan SATPOL PP Tabanan}

Berdasarkan ketentuan yang tersurat dalam kebijakan pemerintah daerah menunjukkan bahwa kedudukan hukum Satuan Polisi Pamong Praja dipimpin oleh seorang Kepala dan berkedudukan di bawah dan bertanggung jawab kepada Kepala Daerah melalui Sekretaris Daerah. Dengan kedudukan SATPOL PP seperti yang disebutkan di atas, maka SATPOL PP menyelenggarakan fungsi:
1. penyusunan program dan pelaksanaan ketentraman dan ketertiban umum, penegakan Peraturan Daerah dan Keputusan Kepala daerah;
2. pelaksanaan kebijakan pemeliharaan dan penyelenggaraan ketentraman dan ketertiban umum di Daerah;

3. pelaksanaan kebijakan penegakan Peraturan Daerah dan Keputusan Kepala Daerah;

4. pelaksanaan koordinasi pemeliharaan dan penyelenggaraan ketentraman dan ketertiban umum serta penegakan Peraturan Daerah, Keputusan Kepala Daerah dengan Aparat Kepolisian Negara, Penyidik Pegawai Negeri Sipil (PPNS) dan atau aparatur lainnya;

5. pengawasan terhadap masyarakat agar mematuhi dan mentaati Peraturan Daerah dan Keputusan Kepala Daerah. 
Sebagai bagian dari perangkat
daerah yang turut menunjang
pembangunan, sesuai dengan
kedudukannya SATPOL PP Tabanan
menjalankan tupoksi ditujukan pada
peningkatan ketentraman dan keteriban
umum, pelaksanaan kebijakan
penegakan peraturan daerah tentang
tata kelola ruang publik di wilayah
kabupaten/kota termasuk juga
penertiban gepeng dan pedagang kaki lima yang tidak sesuai dengan standar kelayakan operasional menjalankan usaha di emper-emper jalan umum sehingga dinilai mengganggu ketertiban umum dan kenyamanan masyarakat.

Maksud dan tujuan kajian terhadap tupoksi SATPOL PP diintensifkan pelaksanaannya di Kabupaten Tabanan adalah bahwa selama ini Kabupaten Tabanan sedang gencar-gencarnya menggalakkan program penataan ruang wilayah yang kondusif bebas dari gepeng dan pedagang kaki lima yang pada dasarnya secara umum banyak meresahkan warga masyarakat sekitar. Tindakan penertiban dilakukan dengan terobosan awal, di satu sisi kota menjadi tertib dan tertata, di sisi lain mencegah untuk kembali maraknya aksi gepeng dan pedagang kaki lima yang beroperasi di jalan-jalan sepanjang wilayah Tabanan sudah dilakukan penyisiran tempat secara bertahap oleh petugas SATPOL PP sehingga gepeng dan pedagang kaki lima tidak kembali mengulang aktifitas yang sudah dilarang.

Untuk dapat tercapainya tujuan kegiatan Survey Kondisi Penertiban oleh SATPOL PP khususnya orientasi pembangunan dan pengembangan wilayah perkotaan maka peneliti menggunakan model kebijakan formulatif dengan melakukan tinjauan terhadap kegiatan penertiban terhadap gepeng dan pedagang kaki lima di Kabupaten Tabanan.

Pendekatan dilakukan dengan mengambil sampel sebanyak 27 orang responden atau $18 \%$ dari 150 warga masyarakat yang berdomisili di kabupaten Tabanan dengan teknik insedental random sampling. Dari 27 orang responden tersebut diperoleh keterangan rata-rata pandangan mereka sangat variatif tentang pelaksanaan kinerja SATPOL PP dalam hal penertiban gepeng dan pedagang kaki lima.

Untuk memahami pengaruh tupoksi SATPOL PP Tabanan dalam penertiban terhadap pembangunan dan pengembangan wilayah dan penataan kota dilaksanakan penelitian dengan metode kuisioner, dimana responden diberikan pertanyaan yang mewakili hal-hal di atas untuk melihat seberapa besar pemahamannya terhadap topik yang ditanyakan. Pemilihan sampel/responden secara proporsional yang difokuskan pada organisasi perangkat daerah, yaitu SATPOL PP Kabupaten Tabanan, satuan kerja pemerintah daerah (SKPD) di propinsi dan kabupaten/kota dengan responden para pejabat pemerintah daerah yang diperkirakan memahami dan dapat memberikan informasi yang relevan Adapun pengelompokan masyarakat yang disurvey meliputi:

A. Berdasarkan Umur
a. Di bawah 30 tahun: $30 \%$
b. 30 sampai 40 tahun: $45 \%$
c. Di atas 40 tahun: $25 \%$

B. Berdasarkan Jenis Kelamin :
a. Laki-Laki : $65 \%$
b. Perempuan : $35 \%$ 
Dari data kuisioner dapat dilihat pemahaman masyarakat Tabanan tentang penertiban kawasan oleh SATPOL PP dan kaitannya terhadap tata kota dan pengembangan keasrian wilayah Tabanan sebagaimana digambarkan pada tabel berikut ini:

Tabel 1: Hasil Kuisioner Formulasi Kebijakan SATPOL PP Kab.Tabanan

\begin{tabular}{|c|l|l|}
\hline No. & Pertanyaan & Tanggapan \\
\hline 1 & $\begin{array}{l}\text { Arti penting tupoksi } \\
\text { penertiban oleh SATPOL PP } \\
\text { bagi masyarakat Tabanan }\end{array}$ & $\begin{array}{l}\text { Semua responden memahami dan mengerti } \\
\text { dengan tupoksi penertiban oleh SATPOL PP }\end{array}$ \\
\hline 2 & $\begin{array}{l}\text { Pengaruh penertiban } \\
\text { kawasan dengan } \\
\text { peningkatan kondisi keasrian } \\
\text { kota }\end{array}$ & $\begin{array}{l}80 \% \text { Responden memahami penertiban kawasan } \\
\text { dengan peningkatan kondisi keasrian kota. } \\
20 \% \text { Responden belum memahami pengaruh } \\
\text { penertiban kawasan dengan peningkatan kondisi } \\
\text { keasrian kota Tabanan. }\end{array}$ \\
\hline 3 & $\begin{array}{l}\text { Peran serta dalam } \\
\text { pelaksanaan kegiatan } \\
\text { penertiban wilayah }\end{array}$ & $\begin{array}{l}\text { Semua responden berperan serta aktif dalam } \\
\text { rencana pelaksanaan kegiatan penertiban wilayah } \\
\text { dengan cara memberikan informasi tentang } \\
\text { sumber-sumber sassaran yang perlu ditertibkan }\end{array}$ \\
\hline 4 & $\begin{array}{l}\text { Orientasi pengelolaan } \\
\text { potensi kawasan dan tata } \\
\text { kelola wilayah Kabupaten } \\
\text { Tabanan dengan } \\
\text { pembangunan Tata Ruang } \\
\text { potensi kawasan memahami orientasi pengelolaan } \\
\text { Tabanan dengan pembangunan Tatan Ruang } \\
10 \% \text { responden berperan serta lebih aktif dalam } \\
\text { mengelola kawasan dan tata kelola wilayah } \\
\text { Kabupaten Tabanan dengan turut mematuhi } \\
\text { prosedur operasional kelayakan tinggal dan } \\
\text { berusaha }\end{array}$ \\
\hline 5 & $\begin{array}{l}\text { Nilai penting penertiban } \\
\text { kawasan dari gepeng dan } \\
\text { pedagang kaki lima }\end{array}$ & $\begin{array}{l}\text { Semua responden mempunyai tanggapan yang } \\
\text { sama tentang pentingnya penertiban kawasan dari } \\
\text { gepeng dan pedagang kaki lima }\end{array}$ \\
\hline 6 & $\begin{array}{l}\text { Keterkaitan antara } \\
\text { penertiban kawasan dari } \\
\text { gepeng pedagang kaki lima } \\
\text { dan Lingkungan asri } \\
\text { terhindar dari citra kumuh }\end{array}$ & $\begin{array}{l}\text { Semua responden mengungkapkan tingginya } \\
\text { keterkaitan antara penertiban kawasan dari gepeng } \\
\text { pedagang kaki lima dan Lingkungan asri terhindar } \\
\text { dari citra kumuh }\end{array}$ \\
\hline 7 & $\begin{array}{l}\text { Kondisi lingkungan } \\
\text { kabupaten/kota Tabanan }\end{array}$ & $\begin{array}{l}70 \% \text { responden menyatakan masih baik dan 30 \% } \\
\text { menyatakan kurang baik }\end{array}$ \\
\hline
\end{tabular}

(Sumber: Hasil Rekapitulasi Data Sebaran Kuisioner Kebijakan Formulatif SATPOL PP Kabupaten Tabanan Tahun 2013.)

Adapun model kebijakan penertiban dilakukan dengan beberapa tahapan, yakni:

a. Tahap pengumpulan opini, hal ini dimunculkan untuk menarik opini publik tentang keberadaan Gepeng dan $\mathrm{PKL}$, dengan cara melakukan survei untuk mengetahui apakah masyarakat setuju atau tidak jika PKL ditertibkan sehingga jika disetujui maka pemerintah memiliki legitimasi kuat untuk menerapkan 
peraturan pemerintah maupun perda sehingga apapun yang dilakukan akan sah dan tidak salah;

b. Tahap pendekatan dan komunikasi dengan pimpinan organisasi Gepeng maupun PKL. Sebelum disosialisasikan akan pemberlakuan perda terlebih dahulu diadakan pendekatan dan komunikasi terhadap para pihak yang berpengaruh atau yang menaungi Gepeng maupun PKL dengan harapan dengan komunikasi ini pimpinan kelompok tersebut bisa memahami dilakukannya penertiban;

c. Tahap Public Hearing, sosialisasi, dan negosiasi dengan komponen Gepeng maupun PKL, tokoh kultural, dan pemerintah. Hal ini dilakukan untuk "menaklukkan" masyarakat yang tidak patuh.

d. MoU Insentif dan Disentif dari hasil kesepakatan.

e. Membuat kesepakatan agar mencegah Gepeng dan PKL kembali beroperasi di wilayah publik. Berisi kesepakatan yang mengatur kemudahan yang akan didapat khususnya PKL di tempat relokasi dan hukuman yang akan diterima apabila tidak patuh (bisa menjadi legalisasi terhadap penggusuran). Kesepakatan yang telah dibangun dengan berbagai kompensasi mengharuskan disepakatinya aturan tersebut

f. Tahap eksekusi pelanggaran kesepakatan/penertiban, dalam bentuk penggusuran bila masih terdapat PKL yang tidak melaksanakan peraturan yang berlaku, dan bagi gepeng yang tertangkap akan di data dan dikembalikan melalui Dinas Sosial Tabanan.

Tindakan penertiban ini disisipi oleh kegiatan pembinaan dengan menampung para gepeng dan pedagang kaki lima yang tertangkap untuk difasilitasi dengan pembimbingan dan pembinaan melalui lembaga sosial seperti balai latihan kerja (BLK) yang sudah disediakan untuk membekali target dengan keterampilan maupun wawasan sehingga bisa bermanfaat ke hal-hal positif pada saat kembali ke lingkungan masyarakat nantinya. Formulasi kebijakan SATPOL PP Tabanan, dapat berupa sumber potensi aparatur daerah yang memiliki tupoksi khusus memberikan arahan yang jelas akan pentingnya penertiban untuk menciptakan tata kelola wilayah kabupaten/kota yang kondusif. Beberapa pertimbangan strategis kebijakan dasar ini dijadikan formulasi oleh kabupaten/kota lain di daerah Bali, antara lain:

1) ketersediaan sumber daya daerah

2) tingkat dan kualitas tata kelola wilayah

3) tingkat daya serap warga terhadap sasaran pembangunan yang dilaksanakan pemerintah daerah

4) kondisi teknis lokasi

5) partisipasi masyarakat dan lintas sektoral

6) Rencana Umum Tata Ruang (RTUR)

Untuk dapat mengetahui dan menentukan formulasi kebijakan SATPOL PP Kabupaten Tabanan, maka tanggapan dan peran serta warga masyarakat menjadi prasyarat mutlak. Dengan mengetahui tanggapan berikut peran serta warga masyarakat terkait

Jurnal IImu Sosial dan Humaniora |501 
dengan keterlibatannya dalam upaya penertiban oleh SATPOL PP berarti menggunakan pendekatan humanistik dalam upaya meningkatkan peranserta mereka yang harus lebih dikedepankan sebagai unsur publik yang turut menjadi pendukung pembangunan daerah. Begitu pula halnya tekait dengan program-program sosialisasi terhadap input-iput teknologi baru atau pun sosialisasi program-program pembangunan tata kota dapat menggunakan pendekatan warga masyarakat dan para pedagang yang sudah memiliki ijin resmi untuk beroperasi.

\section{Implikasi Keberhasilan Model Formulatif Kebijakan SATPOL PP Tabanan dalam Penataan Ruang Wilayah Perkotaan Ditinjau dari Penertiban Gepeng dan Pedagang Kaki Lima}

Seperti telah dijelaskan, kajian kebijakan formulatif dalam hubungannya dengan pembangunan dan pengembangan tata kota oleh Satpol PP lebih cenderung ke arah pembangunan tata ruang wilayah, berarti bahwa manfaat/keuntungan yang dihasilkan tidak seluruhnya diterima langsung oleh pemerintah daerah. Sebagian besar keuntungan tersebut akan dirasakan oleh masyarakat. Hanya saja keuntungan yang diterima masyarakat cukup sulit untuk diukur dengan uang, sehingga dengan kajian pemberdayaan ini dimaksudkan dalam manfaat dan keuntungan adalah manfaat dan keuntungan yang terukur dengan uang yang akan diterima oleh pemerintah dari retribusi, yaitu:

a) Retribusi hasil jual bagi pedagang kecil/eceran yang sudah di lokasikan di los-los di areal pasar resmi akan dikenai retribusi sebesar $5 \%$ dari hasil penjualan.

b) Biaya sewa tempat, setiap pedagang yang menyewa tempat di los-los resmi yang sudah disediakan oleh pihak pemerintah daerah akan dikenai biaya Rp.20.000 perbulan

c) Penghasilan dari parkir pengunjung sebesar Rp.500,- untuk sepeda motor, dan Rp.1.000,- untuk mobil, dan Rp.2.000,- untuk kendaraan umum atau angkut barang. Untuk kendaraan milik pedagang tidak dikenakan biaya.

d) Pengembangan hasil kerajinan tangan dari gepeng ang telah dirazia dan dilakukan pembinaan dan pelatihan di BLK seperti celemek, keset, pas bunga, sendok kayu, parutan kelapa, dan sebagainya

e) Pengembangan usaha pengelolaan hasil limbah industri rumah tangga sebagai kerajinan tangan oleh para gepeng binaan yang telah terampil mengikuti pelatihan dan pembinaan di BLK

f) Pengembangan usaha ekonomiekonomi produktif lainnya.

Ada beberapa parameter model kebijakan formulatif SATPOL PP Tabanan yang dipakai bahan pijakan untuk mengukur kepentingan sosial terbangunnya tata ruang wilayah perkotaan yang kondusif di kabupaten Tabanan antara lain:

1) Paradigma tipe perubahan sosial masyarakat.

Masyarakat Tabanan sebagai mayoitas utama menerima dampak penertiban gepeng dan pedagang kaki lima menjadikan kondisi kawasan lebih asri dan nyaman dan

Jurnal IImu Sosial dan Humaniora |502 
dari segi akomodasi, aktifitas warga dan rutinitas kantor, dan sekolah dapat berjalan dengan lancar. Pada dasarnya gepeng dan pedagang kaki lima di Tabanan sesungguhnya memiliki hasrat untuk dapat memenuhi kehidupan yang lebih baik akan tetapi tidak mau meninggalkan pekerjaan yang selama ini digelutinya, tetapi dengan upaya penertiban, pembinaan dan pelatihan paradigma berpikir tersebut secara perlahan-lahan dapat diarahkan dengan pengembangan keterampilan sehingga mereka dapat membuka jenis usaha yang lebih layak dan resmi.

2) Hubungan historis keberadaan penertiban oleh SATPOL PP

Sebagai aparat pemerintah daerah sudah tentu ada kekuatan hukum/yuridis yang melandasi kedudukan maupun pelaksanaan tupoksi SATPOL PP. Walaupun penertiban yang dilakukan oleh SATPOL PP sering mendapat kecaman dan hujanan bagi korban penggusuran dan penertiban, Akan tetapi keberadaannya sangat dibutuhkan oleh masyarakat dalam menindaklanjuti segala bentuk kesembrautan atau kekumuhan yang mengancam keasrian tata kota dan perihal gepeng maupun pedagang kaki lima juga yang dinilai menyalahi prosedur kelayakan perlu ditindak tegas mengingat itu dikembalikan lagi pada kenyaman warga sekitar yang selama ini merasa resah dengan keberadaan gepeng dan pedagang kaki lima tersebut.
3) Tenaga Kerja

Dengan adanya kecenderungan bahwa usaha kreatif dapat lahir dari pembinaan dan latihan keterampilan di BLK sebagai wujud penempaan bagi pemberdayaan warga binaan yang semula berprofesi sebagai gepeng dan pedagang kaki lima dapat beralih fungsi untuk penciptaan lapangan pekerjaan baru dengan memasarkan hasil kerajinan tangan.

4) Daya Dukung Wilayah

Guna mendukung terciptanya upaya penataan ruang yang bersinergi dengan pembangunan perkotaan maka ada kebutuhan penertiban oleh SATPOL PP Tabanan akan berfungsi sebagai pusat kegiatan penataan ruang wilayah kabupaten/kota.

5) Prasarana Wilayah

Dengan terbangunnya kawasan nyaman dan asri di kabupaten Tabanan memiliki orientasi kebijakan di sektor pembangunan wilayah menjadi lebih terarah dengan konsep terstruktur dan terencana.

Berarti potensi wilayah akan tergarap sesuai dengan peruntukannya. Dengan kegiatan ini akan berfungsi sebagai upaya maju dalam meningkatkan peran serta masyarakat sesuai dengan daya dukung yang dimilikinya dan dilakoninya. Sehingga dalam hal ini pemerintah akan berfungsi sebagai regulator body and fasilitator.

Keberhasilan Tupoksi SATPOL PP Tabanan sebagai Research Modle bagi SATPOL PP di daerah Kabupaten/Kota lain di Provinsi Bali dapat dilihat dari berbagai macam persiapan yang dilakukan, antara lain:

Jurnal IImu Sosial dan Humaniora |503 
a. Persiapan Mobilisasi Personil, yakni mempersiapkan team work dan tenaga pendukung dari satuan keanggotaan SATPOL PP yang akan melaksanakan pekerjaan penataan wilayah mulai tahap awal sampai pelaporan sesuai dengan kerangka acuan kerja.

b. Persiapan Administrasi, yaitu meliputi pengurusan surat ijin penertiban dan menyurati para pihak yang akan disasar kegiatan penertiban serta surat menyurat lainnya yang diperlukan.

c. Persiapan Teknis, meliputi:

1) Persiapan pelaksanaan sarana dan prasana pendukung operasi penertiban dan peralatan pendukung lainnya;

2) Koordinasi awal team work;

3) Menyusun jadwal pelaksanaan operasi penertiban;

4) Menetapkan job description masing-masing personil;

5) Membuat format pelaksanaan tugas dan pelaporan.
Berbagai kebijakan pembangunan Pemerintah Kabupaten Tabanan telah dituangkan dalam Program Pembangunan Daerah (Propeda) yang mana salah satunya diprioritaskan pada bidang tata ruang wilayah yang didukung oleh sektor-sektor lain yang saling terkait. Sedangkan strategi kebijakan umum pembangunan Kabupaten Tabanan diarahkan untuk mempertahankan persatuan dan kesatuan dalam wadah Negara Kesatuan Republik Indonesia yakni menegakkan supremasi hukum, meningkatkan perekonomian, kesejahteraan rakyat serta pembangunan daerah.

Secara khusus Propeda Kabupaten Tabanan Sektor Tata Ruang dan Pembangunan Daerah yang memiliki korelasi terhadap kebijakan penertiban Gepeng dan pedagang kaki lima di Kabupaten Tabanan dapat dilihat pada tabel berikut ini:

Tabel 2: Program Pembangunan Daerah (PROPEDA) Kabupaten Tabanan

\begin{tabular}{|c|c|c|c|}
\hline Sektoral & Program & Kegiatan & Indikator \\
\hline $\begin{array}{l}\text { Tata } \\
\text { Ruang }\end{array}$ & $\begin{array}{l}\text { 1. Menyusun rencana tata } \\
\text { ruang bagi wilayah yang } \\
\text { belum memiliki rencana } \\
\text { tata ruang } \\
\text { 2. Menyusun data lengkap } \\
\text { untuk keperluan proses } \\
\text { perencanaan tata ruang } \\
\text { melalui kerjasama } \\
\text { instansi terkait. } \\
\text { 3. Menyusun data lengkap } \\
\text { untuk keperluan proses } \\
\text { perencanaan tata ruang } \\
\text { melalui kerjasama } \\
\text { instansi terkait. }\end{array}$ & $\begin{array}{l}\text { 1. Penyusunan buku } \\
\text { Rencana Detail Tata } \\
\text { Ruang di semua } \\
\text { kecamatan. } \\
\text { 2. Membuat peraturan } \\
\text { SK dan Perda dalam } \\
\text { hal penataan ruang. } \\
\text { 3. Menyusun pola tata } \\
\text { bangunan perumahan } \\
\text { dan pemukiman }\end{array}$ & $\begin{array}{l}\text { 1. Tersedianya kelembagaan } \\
\text { yang handal dalam } \\
\text { pembangunan tata ruang } \\
\text { 2. Tersedianya rencana tata } \\
\text { ruang yang ideal dan } \\
\text { implementatif } \\
\text { 3. Tingkat kesesuaian } \\
\text { penggunaan lahan untuk } \\
\text { perumahan dan pemukiman } \\
\text { 4. Terwujudnya daftar terlarang } \\
\text { untuk pengembangan } \\
\text { kawasan perumahan dan } \\
\text { pemukiman. }\end{array}$ \\
\hline $\begin{array}{l}\text { Pemban } \\
\text { gunan } \\
\text { Dae } \\
\text { rah }\end{array}$ & $\begin{array}{lr}\text { Pembangunan } & \text { desa/kota } \\
\text { dan kawasan khusus serta } \\
\text { memantapkan program } \\
\text { otonomi daerah }\end{array}$ & $\begin{array}{l}\text { 1. Pembinaan dan } \\
\text { pengembangan desa } \\
\text { 2. Pemantapan } \\
\text { pelaksanaan } \\
\text { pembangunan } \\
\end{array}$ & $\begin{array}{lr}\text { 1. Seimbangnya } & \text { serta } \\
\text { terpadunya pembangunan } \\
\text { antar } & \text { wilayah } \\
\text { desa/kecamatan dalam satu } \\
\text { kesatuan pengembangan }\end{array}$ \\
\hline
\end{tabular}




\begin{tabular}{|l|l|l|l|}
\hline & $\begin{array}{l}\text { desa/kecamatan/kota } \\
\text { 3. Pembangunan sarana } \\
\text { dan prasarana }\end{array}$ & $\begin{array}{l}\text { wilayah pembangunan } \\
\text { 2. Tertib dan teraturnya } \\
\text { pengembangan kawasan } \\
\text { pedesaan dengan pola } \\
\text { terarah } \\
\text { wilayah terpadu }\end{array}$ \\
& $\begin{array}{l}\text { 3. Meningkatnya sarana dan } \\
\text { prasarana } \\
\text { 4. Terwujudnya pengembangan } \\
\text { wilayah dengan sistem } \\
\text { terpadu }\end{array}$ \\
& & \\
\hline
\end{tabular}

(Sumber: Bapeeda Kabupaten Tabanan, 2009.)

$\begin{array}{ccc}\text { Kondisi } & \text { demikian } & \text { semakin } \\ \text { memperlihatkan } & \text { posisi } & \text { strategis } \\ \text { SATPOL PP } & \text { Kabupaten } & \text { Tabanan }\end{array}$ sebagai bagian yang tidak terpisahkan dari upaya Pemerintah Kabupaten Tabanan untuk mensejahterakan maasyarakatnya. Mengingat peran strategis SATPOL PP Kabupaten Tabanan hampir menjadi kunci sub sektor ketertiban dan kenyamanan serta pembangunan yang lainnya. Sehingga ada indikator bahwa SATPOL PP Kabupaten Tabanan dapat menjadi basis kekuatan pengembangan sektor tata ruang dan pembangunan daerah. Dengan demikian arahan strategis yang mesti dikuatkan para stakeholder pembangunan di Kabupaten Tabanan dengan demikian kebijakan formulatif SATPOL PP Tabanan dapat dijadikan acuan oleh kabupaten/kota di daerah Bali lainnya dalam mewujudkan tata ruang wilayah.

Guna lebih mempertegas tekad dan semangat jajaran SATPOL PP dan Pemerintah Daerah sebagai pelaksana dari kebijakan daerah maka upaya sinkronisasi kebijakan antar lembaga/instansi/institusi terkait dengan sektor tata ruang dan pembangunan daerah diimplementasikan melalui penyatuan visi dan misi pembangunan tata ruang wilayah kabupaten/kota secara berkelanjutan.
Untuk dapat mengimplementasikan kebijakan formulatif SATPOL PP Kabupaten Tabanan dapat memberikan pengaruh terhadap tupoksi SATPOL PP di kabupaten/kota lain di daerah Bali dalam penertiban gepeng dan pedagang kaki lima. Maka tolok ukur SATPOL PP dalam menetapkan kebijakan strategis sekaligus merupakan arah untuk mencapai tujuan dan sasaran sektor tata ruang dan pembangunan daerah, yakni:

1) Memperkuat dan mengembangkan usaha pelaksanaan kebijakan pemeliharaan dan penyelenggaraan ketentraman dan ketertiban umum di daerah secara efesien, lestari, dan berbasis kerakyatan.

2) Menggalakkan pelaksanaan kebijakan pemeliharaan dan penyelenggaraan ketentraman dan ketertiban umum di daerah yang berdaya saing dan berwawasan lingkungan dengan pendekatan kewilayahan dan komoditas unggulan.

3) Mengembangkan dan memperkokoh pelaksanaan kebijakan pemeliharaan dan penyelenggaraan ketentraman dan ketertiban umum di daerah dan penataan ruang wilayah serta pembangunan daerah.

4) Memelihara keberlanjutan pelaksanaan tupoksi dengan daya

Jurnal IImu Sosial dan Humaniora|505 
dukung lapisan masyarakat sebagai penggerak motivasi dan informasi untuk penjaringan dan penataan tata kota yang lebih baik.

5) Memperkuat pelaksanaan tupoksi dan sarana prasarana dalam pelaksanaan kebijakan pemeliharaan dan penyelenggaraan ketentraman dan ketertiban umum di daerah.

Keberadaan SATPOL PP di Kabupaten Tabanan menjadi sangat strategis sebagai model pelaksanaan kebijakan pemeliharaan dan penyelenggaraan ketentraman dan ketertiban umum di daerah. Mengingat berbagai potensi, tantangan, dan peluang yang ada akan dapat terjawab sesuai dengan arahan kebijakan strategis pembangunan daerah. Keberhasilan pelaksanaan tupoksi SATPOL PP Tabanan juga memberikan efek domino bagi penataan struktur tata ruang wilayah dan pembangunan daerah secara berkelanjutan.

Hal ini sangat sejalan dengan kondisi pengembangan pelaksanaan kebijakan pemeliharaan dan penyelenggaraan ketentraman dan ketertiban umum di daerah Tabanan dan daerah kabupaten/kota lain di Bali pada umumnya yang nyata-nyata berorientasi pada kesejahteraaan masyarakat melalui peningkatan keterampilan, permodalan, produktifitas produksi usaha kreatif mandiri yang lahir dari tangan-tangan terampil warga binaan merupakan bekas gepeng atau pedagang kaki lima yang telah terjaring dan diberdayakan dengan memperoleh bekal pengetahuan dan keterampilan hasil tempaan dari balai latihan kerja (BLK) secara simultan. Oleh sebab itu, dalam pengembangannya perlu memperhatikan aspek-aspek yang mempengaruhinya, yaitu potensi sumberdaya daerah, sumberdaya dalam hal memfasilitasi pembedayaan pengembangan kemampuan kreatif (dinas sosial yang bersedia menampung) seperti BLK yang difasilitasi pemerintah daerah. Kenyataan ini akan dapat terpolakan dalam suatu sistem pengembangan, peningkatan dan penguatan tupoksi SATPOL PP sebagai lembaga pelayanan yang berbasis pelaksanaan kebijakan pemeliharaan dan penyelenggaraan ketentraman dan ketertiban umum di daerah.

\section{PENUTUP}

Formulasi kebijakan SATPOL PP Tabanan, dapat berupa sumber potensi aparatur daerah yang memiliki tupoksi khusus memberikan arahan yang jelas akan pentingnya penertiban untuk menciptakan tata kelola wilayah kabupaten/kota yang kondusif. Kajian kebijakan formulatif dalam hubungannya dengan pembangunan dan pengembangan tata kota oleh Satpol PP lebih cenderung ke arah pembangunan tata ruang wilayah, sebagian besar keuntungan tersebut akan dirasakan oleh masyarakat, berupa retribusi hasil jual, penyediaan tempat permanen berupa los-los resmi, penyediaan jasa pelayanan parkir, termasuk pengembangan jenis usaha kreatif hasil kerajinan tangan warga binaan bekas penjaringan ketertiban. Hal ini sangat dipengaruhi oleh tipe perubahan sosial kemasyarakatan, kinerja SATPOL PP, tenaga kerja, daya dukung wilayah, dan prasarana wilayah. Kebijakan pembangunan Pemerintah Kabupaten Tabanan telah dituangkan dalam 
Program Pembangunan Daerah (Propeda) yang mana salah satunya diprioritaskan pada bidang tata ruang wilayah yang didukung oleh sektorsektor lain yang saling terkait. Keberhasilan pelaksanaan tupoksi SATPOL PP Tabanan juga memberikan efek domino bagi penataan struktur tata ruang wilayah dan pembangunan daerah secara berkelanjutan.

Beberapa saran sebagai langkah strategis dalam menyusun kebijakan pemeliharaan dan penyelenggaraan ketentraman dan ketertiban umum di daerah bagi SATPOL PP Kabupaten Tabanan, antara lain:

1. Membuat desain rancangan kebijakan pemeliharaan dan penyelenggaraan ketentraman dan ketertiban umum di daerahyang terpadu, dan terintegrasi dengan nilai-nilai kearifan lokal masyarakat daerah khususnya dan masyarakat desa pada umumnya.

2. Sebagai aparatur daerah bertugas menyusun dan menetapkan kebijakan pemeliharaan dan penyelenggaraan ketentraman dan ketertiban umum di daerah.

3. Merehabilitasi para gepeng dan pedagang kaki lima yang terjaring agar difasilitasi lebih lanjut oleh lembaga sosial yang difasilitasi daerah seperti BLK untuk pengembangan dan penempaan, serta latihan dari segi penanam wawasan dan keterampilan manajemen usaha mandiri kreatif dan inovatif.

4. Pemerintah daerah melalui instansi terkait semestinya memfasilitasi secara intensif kelompok-kelompok usaha rintisan dalam kegiatan pelatihan dan pengembangan produksi sehingga manajemen pemasarannya tertata rapi dan terprosedur dengan baik.

5. Melakukan pembinaan-pembinaan kepada para gepeng dan pedagang kaki lima agar mau, tahu, dan mampu berperan dalam pemeliharaan dan penyelenggaraan ketentraman dan ketertiban umum di daerah.

6. Meningkatkan koordinasi dan komunikasi antara warga masyarakat dengan aparat SATPOL PP untuk menjaga stabilitas ketentraman dan ketertiban umum di daerah.

7. Meningkatkan usaha kerjasama antara Pemerintah Kabupaten Tabanan dengan pemerintahpemerintah daerah lain terkait dengan pembinaan gepeng dan pedagang kaki lima di bidang pembekalan wawasan dan keterampilan.

\section{DAFTAR PUSTAKA}

Sunggono, Bambang, 1998, Metodologi Penelitian Hukum (Suatu Pengantar), PT.Raja Grafindo Persada, Jakarta.

Rumawan Salain, Putu, 2011. RTRWP Bali No.16 Tahun 2009 sebagai Pedoman Penataan Ruang dan Lingkungan bagi Pembangunan Berkelanjutan. Jurusan Arsitektur, Fakultas Teknik, Universitas Udayana.

Windari, Ratna, 2011, "Penegakan Hukum Terhadap Perlindungan Anak di Indonesia (Kajian Normatif atas Bekerjanya Hukum Dalam Masyarakat", Jurnal Media Komunikasi FIS, Vol.10, No.1, April

Jurnal IImu Sosial dan Humaniora |507 
2011, Singaraja: Fakultas IImu Sosial Undiksha

_, 2011, "Korelasi Yuridis Rencana Tata Ruang Wilayah Propinsi (RTRWP) Terhadap Keajegan Alam Bali”, Jurnal Media Komunikasi FIS, Edisi Khusus PPKn Vol.10, No.3, Desember 2011, Singaraja: Fakultas IImu Sosial Undiksha.

Indonesia, Peraturan Pemerintah Nomor 32 Tahun 2004 tentang Pedoman Satuan Polisi Pamong Praja.
(Lembaran Negara Tahun 2001 Nomor 118). ,Peraturan Menteri Dalam Negeri Nomor 26 Tahun 2000 tentang PedomanProsedur Tetap Operasional Satuan Polisi Pamong Praja. (Lembaran Negera Nomor 53, TLN 4389). ,Pemerintah DaerahKabupaten Tabanan No.12 Tahun 2002 tentang Ketertiban Umum, (Lembaran Daerah Kabupaten Tabanan Tahun 2002 Nomor 32). 